\title{
Physiological Effects of Liquid Applications of a Seaweed Extract and a Humic Acid on Creeping Bentgrass
}

\author{
Xunzhong Zhang, E.H. Ervin, ${ }^{1}$ and R.E. Schmidt \\ Department of Crop and Soil Environmental Sciences, Virginia Polytechnic Institute and State University, \\ Blacksburg, VA 24061-0404
}

AdDITIONAL INDEX words. Agrostis stolonifera, chlorophyll fluorescence, fertilization, Fv/Fm, superoxide dismutase

\begin{abstract}
A variety of organic materials such as humic substances, seaweed extracts (SWE), organic matter, and amino acids are being used as fertilizer supplements in commercial turfgrass management. Among them, SWE and humic acid (HA) are widely used in various biostimulant product formulations. These compounds have been reported to contain phytohormones and osmoprotectants such as cytokinins, auxins, polyamines, and betaines. Manufacturer claims are that these products may supplement standard fertility programs by reducing mineral nutrient requirements while improving stress tolerance. There is a lack of season-long, field-based evidence to support these claims. This study was conducted to investigate the influence of monthly field applications of SWE, HA, and high and low seasonal fertilization regimes on the physiological health of fairway-height creeping bentgrass (Agrostis stolonifera L.). Plots were treated monthly with SWE at $16 \mathrm{mg} \cdot \mathrm{m}^{-2}$ and $\mathrm{HA}(70 \%$ a.i. $)$ at $38 \mathrm{mg} \cdot \mathrm{m}^{-2}$ alone, or in combination, and were grown under low $\left(20 \mathrm{~kg}^{\prime} \cdot \mathrm{h}^{-1} / \mathrm{month}\right)$ or high nitrogen $\left(50 \mathrm{~kg} \cdot \mathrm{ha}^{-1} / \mathrm{month}\right)$ fertilization regimes during 1996 and 1997 . Endogenous antioxidant superoxide dismutase (SOD) activity, photochemical activity (PA), and turf quality were measured in July of each year. Superoxide dismutase activity was increased by $46 \%$ to $181 \%$, accompanied by a PA increase of $9 \%$ to $18 \%$, and improved visual quality of bentgrass in both years. There was no significant fertilization $\times$ supplement interaction. Although not part of our original objectives, it was noted that significantly less dollar spot (Sclerotinia homoeocarpa F.T. Bennett) disease incidence occurred in supplement-treated bentgrass. Our results indicate that increased SOD activity in July due to SWE and/or HA applications improved overall physiological health, irrespective of fertilization regime. This suggests that these compounds may be beneficial supplements for reducing standard fertilizer and fungicide inputs, while maintaining adequate creeping bentgrass health.
\end{abstract}

Creeping bentgrass (Agrostis stolonifera L.) is an extensively used cool season grass for low-cut turf areas such as golf course fairways and greens. A preference for this species and increasing demand by the public for high quality golf playing surfaces have expanded bentgrass use farther into the South and other regions of the Unites States (White, 1996). However, unfavorable summer environmental conditions often reduce the quality of creeping bentgrass in many areas. Less stress tolerance and poor quality of cool-season turfgrass species are often associated with a shallow root system and excess shoot growth caused by an over-fertilization with nitrogen and over-irrigation (Hull, 1992).

Water deficit, high radiation and high temperatures during the summer may increase oxidative stress leading to cellular damage and growth reduction of cool-season plants (Demmig-Adams and Adams, 1992; Lawlor, 1995). It is well established that environmental stress may damage plant cells through production of reactive oxygen species (ROS) including superoxide, hydrogen peroxide, hydroxyl anions, and singlet oxygen (Scandalios, 1997). When stress results in decreased efficiency of photosynthetic electron transport, electrons can react to reduce molecular oxygen, resulting in the overproduction of ROS (Smirnoff, 1995). Plant antioxidant metabolites and enzymes protect plant cells by scavenging these ROS (Polle, 1997). Superoxide dismutase is an efficient antioxidant enzyme for scavenging superoxide anions (Bowler et al., 1992; Scandalios, 1997). Greater antioxidant content has been associated positively with turfgrass stress tolerance (Zhang, 1997; Zhang and Schmidt, 1999, 2000a).

Seaweed (Ascophyllum nodosum Jol.) extracts (SWE) and hu-

Received: 15 Feb. 2002. Accepted for publication 10 Feb. 2003

${ }^{1}$ Corresponding author; e-mail ERVIN@VT.EDU. mic acid (HA) are two novel materials that have shown promise for protecting turfgrasses against oxidative stress. Much early work by Schmidt and collaborators focused on refining appropriate dilution rates of seaweed extracts and HA based on turfgrass responses such as leaf growth rate and senescence (Goatley and Schmidt, 1990), nutrient uptake (Yan, 1993), root mass (Nabati et al., 1994), and photochemical activity (Zhang, 1997). These studies have shown that certain rates of generic and commercial formulations of SWE and/or HAcan improve turfgrass quality and resistance to environmental stresses such as drought (Zhang, 1997) and salinity (Nabati, et al., 1994). Further research indicated that improved stress resistance was associated with increases in antioxidant contents and activities (Zhang and Schmidt, 1997; Zhang and Schmidt, 1999, 2000b). All of these studies were conducted under uniform fertilization. Because the chemical components of SWE and HA have yet to be completely characterized and tested for specific activity, we do not currently understand the physiological or biochemical bases of SWE and/or HA's effects on antioxidants and other stress responses. However, information from other researchers has provided some clues as to constituents and possible modes of action.

Fike et al. (2001) reported that SWE derived from A. nodosum contains various compounds including amino acids and micronutrients; they also reported hormonal activity equivalent to $50 \mathrm{mg} \cdot \mathrm{L}^{-1}$ kinetin. Additionally, auxin and cytokinins have been identified and quantified in SWE using GC-MS techniques (Crouch and Van Staden, 1993; Sanderson and Jameson, 1986; Sanderson et al., 1987; Senn, 1987). Lastly, three betaine forms have been quantified in A. nodosum extracts (Blunden et al., 1986). Quarternary ammonium compounds such as the betaines are thought to play a pivotal role in plant cytoplasmic adjustment 
in response to osmotic stresses (Rhodes and Hanson, 1993).

Humic acids, the major acid extractable component of humic substances, consist of a hydrophobic framework of aromatic rings linked by flexible carbon chains, with alcohol, amide, amine, carboxylic, carbonyl, phenol, and quinone functional groups (Davies and Ghabbour, 1998). Several researchers have noted that various sources of HA may improve plant nutrient uptake (Adani et al., 1998), increase root growth (Chen and Aviad, 1990; Clapp et al., 1998), enhance enzyme activity, and promote stress tolerance (Chen and Aviad, 1990). Liu et al. (1998) reported that $400 \mathrm{mg} \cdot \mathrm{L}^{-1}$ humic acid, supplied hydroponically, enhanced net photosynthesis, root dehydrogenase activity, and root mass of creeping bentgrass. Two hormonal mode of action possibilities for HA involve the auxin-like activity reported by O'Donnell (1973) and Nardi et al. (1994) and increased polyamine content associated with stimulation of root growth reported by Young and Chen (1997).

Seaweed extracts and humic acids from multiple sources are currently being used in many commercial turf products. Some manufacturers claim these products may improve turfgrass performance under environmental stress when used in conjunction with a standard fertilization program (Sachs, 1996). Further, many claim that proper use of these products improves turfgrass quality with reduced input of mineral fertilizers (Sachs, 1996). Scant research exists concerning the interaction of SWE and/or HA with mineral nutrition on field-managed turfgrass. Therefore, the objectives of this research were to investigate the influence of monthly applications of SWE and/or HA on superoxide dismutase (SOD) activity, photochemical activity (PA), and turf visual quality of creeping bentgrass subjected to low and high seasonal fertilization regimes.

\section{Materials and Methods}

This study was conducted at the Virginia Tech Turfgrass Research Center, Blacksburg, Va., from 14 May 1996 through 3 Dec. 1997. A mature 'Penncross' creeping bentgrass area, grown on a Groseclose silt loam soil (clayey, Kaolinitic, mesic Typic Hapludult, pH 6.2, OM 2.2\%), was mowed at $0.625 \mathrm{~cm}$ three times weekly. A curative approach to pest control was followed. No insecticide or herbicide applications were needed during the study. However, there was sustained dollar spot (Sclerotinia homoeocarpa F.T. Bennett) disease pressure during both summers. Because treatment differences were striking, dollar spot damage ratings were taken in July of both years before applying a curative rate $\left(1.4 \mathrm{~kg} \cdot \mathrm{ha}^{-1}\right)$ of Chipco 26019 FLO (iprodione: 3-(3.5dicholorophenyl)-N-(1-methylethyl)-2.4-dioxo-1-imidazolidine carboxamide; a.i. 23.3\%). Although not originally part of the objectives of this study, dollar spot incidence was evaluated based on a visual scale of 1 to 9 , with 1 indicating no damage and 9 indicating a complete blighting of the plot. After disease ratings were taken, iprodione was applied to stop the disease and allow for recovery. The turfgrass was uniformly irrigated to prevent drought stress on an as-needed basis with a traveling sprinkler (Rain Coach; Fresno, Calif.) that applied $2.5 \mathrm{~cm} \cdot \mathrm{h}^{-1}$.

A split plotexperimental design was used with four replications. The main plot consisted of high and low fertilization treatments as follows: 1) low fertilization: $\mathrm{N}$ from urea at $20 \mathrm{~kg} \cdot \mathrm{ha}^{-1} ; \mathrm{P}$ from triple super phosphate $(21 \% \mathrm{P})$ at $2.8 \mathrm{~kg} \cdot \mathrm{ha}^{-1}$; and $\mathrm{K}$ from potassium chloride $(50 \% \mathrm{~K})$ at $\left.10.8 \mathrm{~kg} \cdot \mathrm{ha}^{-1} ; 2\right)$ high fertilization: $\mathrm{N}$ at $50 \mathrm{~kg} \cdot \mathrm{ha}^{-1} ; \mathrm{P}$ at $5.6 \mathrm{~kg} \cdot \mathrm{ha}^{-1}$; and $\mathrm{K}$ at $21.6 \mathrm{~kg} \cdot \mathrm{ha}^{-1}$. Urea was dissolved in water and the solution was sprayed over foliage every $30 \pm 2 \mathrm{~d}$ from 24 May to 26 Nov. 1996 and 29 Apr. to 29 Nov. 1997. The $\mathrm{N}$ rates were $140-160 \mathrm{~kg} \cdot \mathrm{ha}^{-1}$ per season for the low regime and 350 to $400 \mathrm{~kg} \cdot \mathrm{ha}^{-1}$ per season for the high regime. Triple super phosphate (0-46-0) and potassium chloride (0-0-60) were applied to each plot with a shaker jar and watered in on 24 May, 17 July, and 15 Oct. 1996 and 28 May, 21 July, and 17 Oct. 1997.

Separate subplots, $1.5 \times 1.8 \mathrm{~m}$, were treated with alkaline extracts of $A$. nodosum at $16 \mathrm{mg} \cdot \mathrm{m}^{-2}$ and acid extracts of leonardite $\left(70 \%\right.$ a.i.) at $38 \mathrm{mg} \cdot \mathrm{m}^{-2}$ alone, or in a combination, every $30 \pm 3$ d beginning on 14 May to 3 Dec. 1996 and 29 Apr. to 23 Nov.1997. These supplements were mixed with water and the solutions were applied evenly over each plot at $35 \mathrm{ml} \cdot \mathrm{m}^{-2}$ using a compressed air sprayer at $290 \mathrm{kPa}$. Both SWE and HA were obtained from Plant-Wise Biostimulants, Inc. (Louisville, Ky.). The humic acid used in this study was an extracted source from leonardite. The SWE product used in this study is estimated to contain the equivalent of $50 \mathrm{mg} \cdot \mathrm{L}^{-1}$ of kinetin according to a bioassay using radish (Raphanus sativus L.) cotyledons as reported by Acadian Seaplants Limited (Nova Scotia, Canada).

Sample collection for SOD analysis in July 1996 and 1997 consisted of permitting the grass to grow for one week without mowing and then sampling leaf blade tissue removed by mowing with a $55-\mathrm{cm}$-wide greens-type reel mower set at a $0.625-\mathrm{cm}$ height. Each bulk plot leaf tissue sample was frozen immediately with liquid nitrogen and stored at $-20{ }^{\circ} \mathrm{C}$ for subsequent SOD activity analysis. Fresh leaf samples $(1,000 \mathrm{mg})$ were homogenized in $10 \mathrm{~mL}$ of $0.05 \mathrm{M} \mathrm{Na}_{2} \mathrm{HPO}_{4} / \mathrm{NaH}_{2} \mathrm{PO}_{4}(\mathrm{pH} 7.0)$ buffer. The homogenates were filtered through four layers of
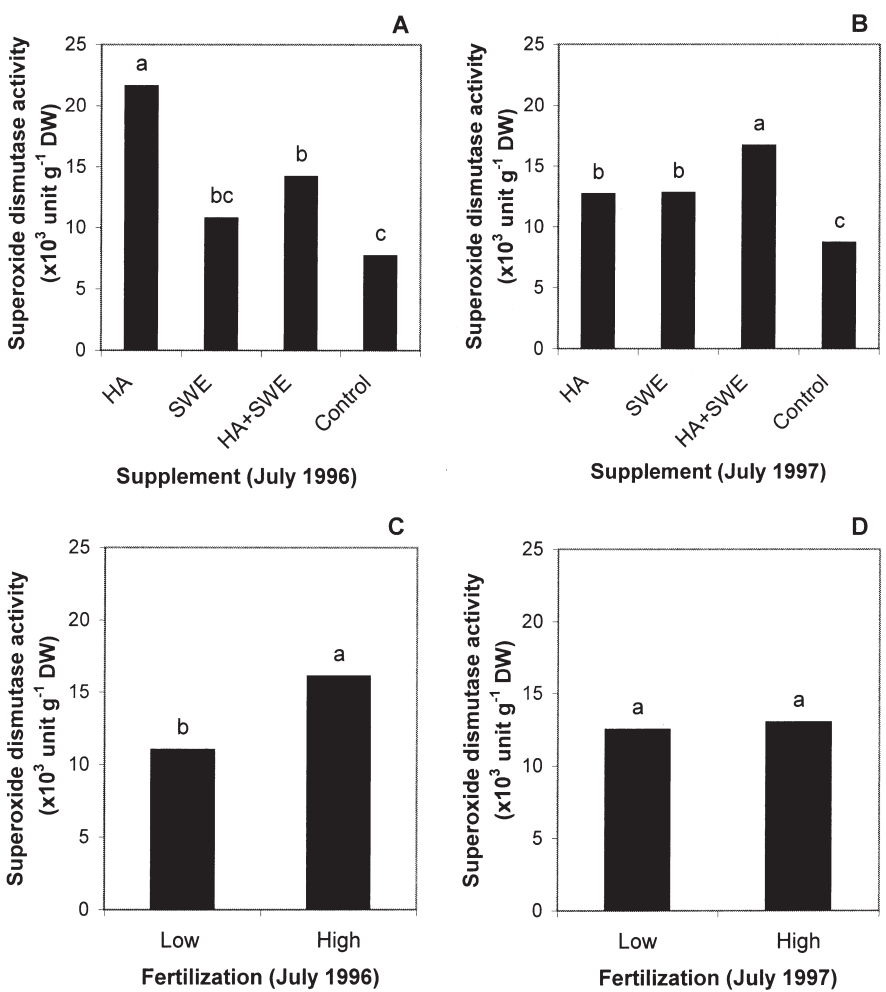

Fig. 1. Superoxide dismutase (SOD) activity in creeping bentgrass during July 1996 and July 1997 as influenced by supplements and fertilization. Seaweed extracts and humic acid were applied every $30 \mathrm{~d}, 3 \mathrm{~d}$ from 14 May to $3 \mathrm{Dec}$. 1996 and $29 \mathrm{Apr}$. to $23 \mathrm{Nov} .1997$ at 16 and $38 \mathrm{mg} \cdot \mathrm{m}^{-2}$, respectively (treatments within each data set marked with same letters are not different significantly at $P \leq 0.05$ ). 
cheesecloth and then centrifuged at $4{ }^{\circ} \mathrm{C}$ for $20 \mathrm{~min}$ at $15,000 \mathrm{~g}$. The supernatants were collected and used for the SOD assay.

Superoxide dismutase activity was analyzed according to the procedure of Giannopolitis and Ries (1977). One enzyme unit of SOD activity is defined as the amount of enzyme required to cause $50 \%$ inhibition of nitro blue tetrazolium reduction measured at $560 \mathrm{~nm}$ on a spectrophotometer.

The function of the photosynthetic system of the turf canopy was probed by measuring chlorophyll fluorescence with a dual wavelength fluorometer (OS-50; Opti-Sciences, Inc. Tyngsboro, Mass.) immediately before leaf samples were taken for SOD analysis. Photochemical activity (Fv/Fm) and chlorophyll content (Fm730nm/Fm690nm) were obtained based on chlorophyll fluorescence signals (Schmidt et al., 1999; Zhang and Schmidt, 2000b). The turfgrass canopy was covered in dark for $15 \mathrm{~min}$. and then exposed briefly to light at which time a reading was taken from each plot randomly. An average of three readings from each plot were used for data analysis. In addition, turf quality was rated on a visual scale of 1 to 9 , with 9 indicating the best quality in July 1996 and 1997. Dollar spot incidence was rated on a visual scale of 1 to 9 , with 1 indicating no dollar spot and 9 indicating complete blighting of the plot in July of both years.

Data from 1996 and 1997 were analyzed separately since the year was not considered as a variable in the experimental design. Each data set was subjected to ANOVA and main effects and the interactions of the two factors (fertilization $\times$ supplement treatment) were evaluated. Since the interactions for each data set were not significant, mean separations for supplement treatments were ascertained using Duncan's multiple range test based on the averages across both fertilization regimes (SAS, 1996).
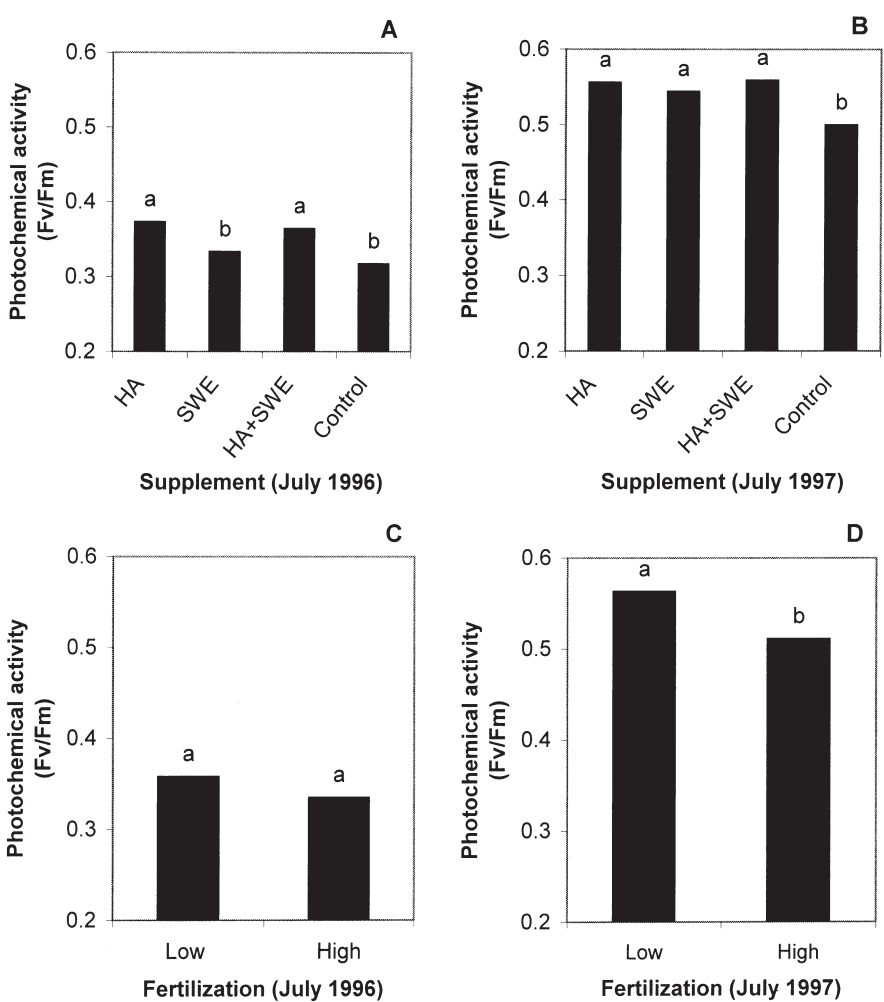

Fig. 2. Photochemical activity (Fv/Fm) in creeping bentgrass during July 1996 and July 1997 as influenced by supplements and fertilization. Seaweed extracts and humic acid were applied every $30 \pm 3$ d from 14 May to 3 Dec. 1996 and 29 Apr to 23 Nov. 1997 at 16 and $38 \mathrm{mg} \cdot \mathrm{m}^{-2}$, respectively (treatments within each data set marked with same letters are not different significantly at $P \leq 0.05$ ).

\section{Results}

When measured during July 1996, application of HA or HA + SWE increased SOD activity by $181 \%$ and $84 \%$, respectively (Fig. 1A). When measured during July 1997, application of HA, SWE, and HA + SWE enhanced SOD activity by $46 \%, 47 \%$, and $92 \%$, respectively (Fig. 1B). The highest SOD activity during July 1997 was obtained in bentgrass treated with HA + SWE. High fertilization increased the SOD activity of creeping bentgrass in July 1996 by 46\% (Fig. 1C), but not in July 1997 (Fig. 1D). The fertilization $\times$ supplement interaction was not significant for SOD activity in 1996 or 1997.

When measured during July 1996, application of HA or HA + SWE increased PA by $18 \%$ and $15 \%$, respectively (Fig. 2A). In July 1997, application of HA, SWE, and HA + SWE enhanced PA by $11 \%, 9 \%$, and $12 \%$, respectively (Fig. 2B); however, high fertilization decreased PA by $10 \%$ in July 1997 (Fig. 2D), but not in July 1996 (Fig. 2C). The fertilization $\times$ supplement interaction was not significant for PA in 1996 or 1997.

Application of HA and SWEalone or in combination improved turf quality in July 1996 (Fig. 3A) and July 1997 (Fig. 3B), except SWE alone in July 1996. The greatest turf quality was observed when the grass was treated with HA and SWE in combination (Fig. 3A and B). High fertilization improved turf quality in July 1996 (Fig. 3C), but not in July 1997 (Fig. 3C). The fertilization $\times$ supplement interaction was not significant for turf quality in 1996 or 1997.

Dollar spot disease incidence was generally reduced by application of all supplement treatments under low or high fertilization when evaluated during July 1996 (Table 1). As expected, higher
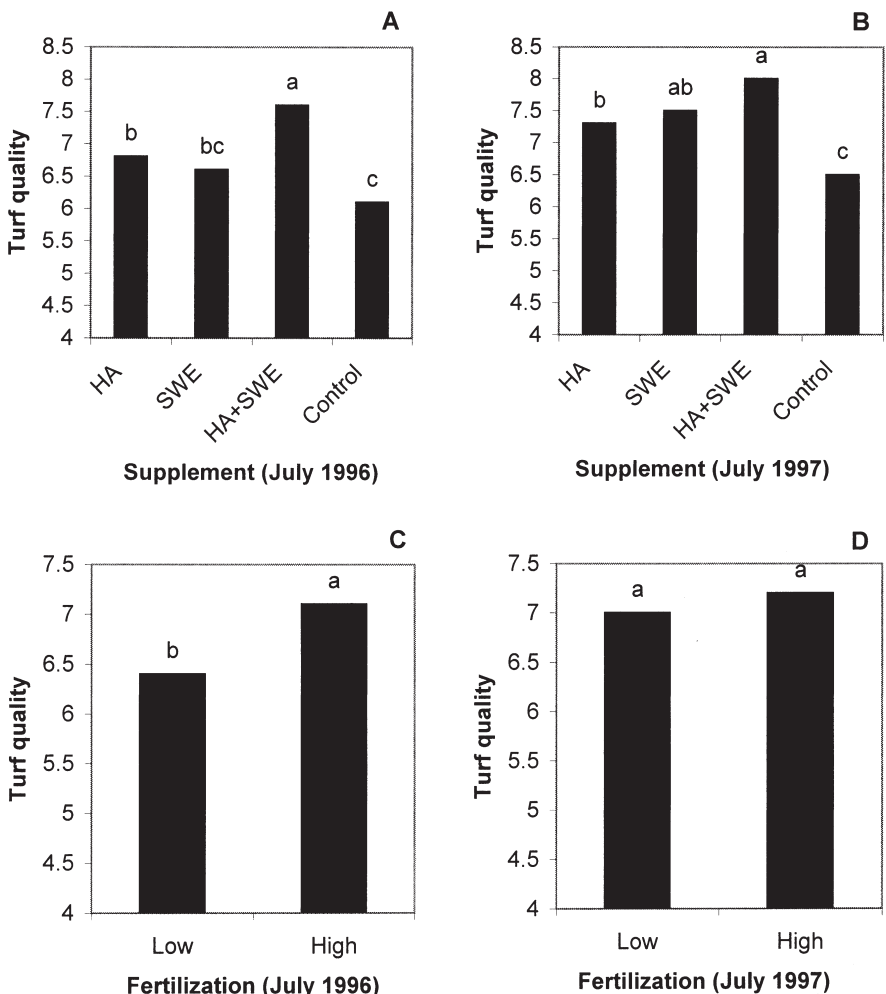

Fig. 3. Turf quality of creeping bentgrass on 11 July 1996 and 25 July 1997 as influenced by supplements and fertilization. Seaweed extracts and humic acid were applied every $30 \pm 3 \mathrm{~d}$ from 14 May to 3 Dec. 1996 and 29 Apr. to 23 Nov. 1997 at 16 and $38 \mathrm{mg} \cdot \mathrm{m}^{-2}$, respectively (treatments within each data set marked with same letters are not different significantly at $P \leq 0.05$ ). 
Table 1. Incidence of dollar spot on creeping bentgrass as influenced by supplement and fertilization; SWE = seaweed extracts, $\mathrm{HA}=$ humic acid.

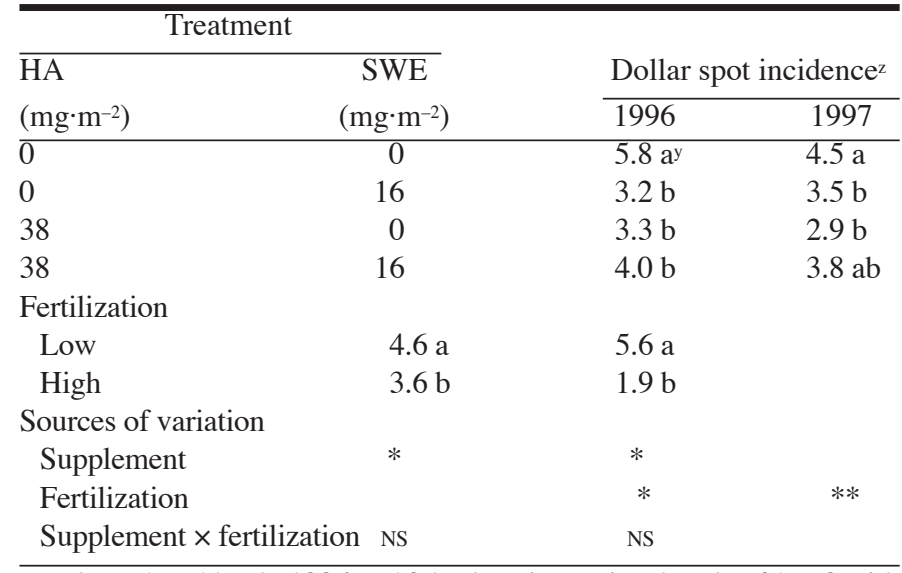

${ }^{2}$ Evaluated on 11 July 1996 and 25 July using a visual scale of 1 to 9 with $1=$ no dollar spot and $9=$ a complete blighting of the plot

yValues followed by same letters in each column for each data set are not significantly different at $P \leq 0.05$.

ss, ,***Nonsignificant or significant at $P \leq 0.05$ or 0.01 , respectively.

nitrogen application reduced disease incidence on field grown creeping bentgrass in both years. There was no significant fertilization $\times$ supplement interaction for dollar spot incidence.

\section{Discussion}

The results of this study indicate that foliar application of SWE and HAalone, or in combination, generally increased SOD activity of field grown creeping bentgrass in July (Fig. 1A and B). These increases were associated with greater photochemical activity, better turf quality, and less dollar spot disease incidence. These results are consistent with those of Coelho et al. (1997), Fike et al. (2001), and Zhang and Schmidt, (1999, 2000a). When creeping bentgrass experiences photooxidative stress, the photosynthetic apparatus is one of the primary targets of oxidative damage. In mature leaves, a major fraction of cellular SOD (60\% to $80 \%)$ is located in chloroplasts (Bowler et al., 1992). Our results indicate that increased SOD activity in July due to SWE and/or HA applications may have improved overall bentgrass physiological health, regardless of whether the bentgrass received the low or high fertilization treatments. This suggests that the beneficial influence of these compounds on turfgrass field performance could be achieved under reduced, but nutritionally adequate, fertilization.

Evidence regarding how SWE and HA may promote SOD and photochemical activity is lacking; however, we speculate that the reported hormonal and compatible osmolyte content of these substances may play a causative role. The application of exogenous auxins, cytokinins, or glycinebetaine has been shown to result in increased endogenous levels of the hormones and osmoprotectants (Aueret al., 1999; Rhodes and Hanson, 1993). Increased endogenous concentrations of the four candidate compound groups — cytokinins, auxins, polyamines, and betaines - have all been associated with membrane stabilization leading to protection of PSII activity during osmotic and temperature stress (Aldesuquy, 2000; Nooden and Leopold, 1988; Papageorgiou et al., 1991; Williams et al., 1992). Yan et al. (1997) reported that SWE increased membrane lipid unsaturation and fluidity leading to more favorable perennial ryegrass leaf water potential under drought.
Investigations on the role of these compounds in the physiological and biochemical mode of action of SWE and HA are currently underway. Considerable research remains to be completed to gain a clearer understanding of how alkaline extracts of A. nodosum (SWE), acid extracts of leonardite (HA), or their combination increase the physiological health of turfgrasses and other plants under environmental stress. It is clear from the results herein, however, that supplementation of standard fertilization programs with SWE and/or HA may bolster creeping bentgrass defense systems to allow maintenance of acceptable quality with fewer fungicidal and fertilizer inputs.

\section{Literature Cited}

Adani, F., P. Genevini, P. Zaccheo, and G. Zocchi. 1998. The effect of commercial humic acid on tomato plant growth and mineral nutrition. J. Plant Nutr. 21:561-575.

Aldesuquy, H.S. 2000. Effect of indol-3-yl-acetic acid on photosynthetic characteristics of wheat flag leaf during grain filling. Photosynthetica 38(1):135-141.

Auer, C.A., V. Motyka, A. Brezinova, and M. Kraminek. 1999. Endogenous cytokinin accumulation and cytokinin oxidase activity during shoot organogenesis of Petunia hybrida. Physiol. Plant. 105:141-147.

Blunden, G., A.L. Cripps, S.M. Gordon, T.G. Mason, and C.H. Turner. 1986. The characterization and quantitative estimate of betaines in commercial seaweed extracts. Bot. Marina 8:138-143.

Bowler, C., M.Van Montagu, and D. Inze. 1992. Superoxide dismutase and stress tolerance. Annu. Rev. Plant Physiol. Mol. Biol. 43:83-116.

Chen, Y. and T. Aviad. 1990. Effects of humic substances on plant growth, p. 161-186. In: Y. Chen and T. Aviad (eds.). Humic substances in soil and crop sciences. Amer. Soc. Agron.-Soil Sci. Soc. Amer., Madison, Wis.

Clapp, C.E., R. Liu, V.W. Cline, Y. Chen, and M.H.B. Hayes. 1998. Humic substances for enhancing turfgrass growth, p. 227-234. In: G. Davies and E.A. Ghabbour (eds.). Humic substances: Structures, properties and uses. Royal Soc. Chem. Publ., Cambridge, U.K.

Coelho, R.W., J.H. Fike, R.E. Schmidt, X. Zhang, V.G. Allen, and J.P. Footenot. 1997. Influence of seaweed extract on growth, chemical composition, and superoxide dismutase activity in tall fescue, p. 163-167. In: Proc. of Amer. Forage Grassl. Council, Ft. Worth. Texas, 13-16 Apr.

Crouch, I.J. and J. Van Staden. 1993. Evidence for the presence of plant growth regulators in commercial seaweed products. Plant Growth Regulat. 13:21-29.

Davies, G. and E.A. Ghabbour. 1998. Preface. In: G. Davies, E.A. Ghabbour, and K. A. Khairy (eds.). Humic substances structures, properties and uses. Royal Soc. Chem. Publ., Cambridge, U.K.

Demmig-Adams, B. and W.W. Adams III. 1992. Photoprotection and other responses of plants to high light stress. Annu. Rev. Plant Physiol. Mol. Biol. 43:599-626.

Fike, J.H., V.G. Allen, R.E. Schmidt, X. Zhang, J.P. Fontenot, C.P Bagley, R.L. Ivy, R.R. Evans, R.W. Coelho, and D.B. Wester. 2001 Tasco-Forage: I. Influence of a seaweed extract on antioxidant activity in tall fescue and in ruminants. J. Animal Sci. 79:1011-1021.

Giannopolitis, C.N. and S.K. Ries. 1977. Superoxide dismutase. I. Occurrence in higher plants. Plant Physiol. 59:309-314.

Goatley, Jr., J.M. and R.E. Schmidt. 1990. Anti-senescence activity of chemicals applied to kentucky bluegrass. J. Amer. Soc. Hort. Sci. 115 654-656.

Hull, R.J. 1992. Energy relations and carbohydrate partitioning in turfgrasses, p. 175-205. In: D.V. Waddington, R.N. Carrow, and R.C. Sherman (eds.). Amer. Soc. Agron Turfgrass Agron. Monogr. 32.

Lawlor, D.W. 1995. The effects of water deficit on photosynthesis, $p$. 129-160. In: N. Smirnoff (ed.). Environment and plant metabolism: flexibility and acclimation. BIOS Scientific Publ. Ltd. Oxford, U.K.

Liu, C.R., J. Cooper, and D.C. Bowman. 1998. Humic acid application affects photosynthesis, root development, and nutrient content of 
creeping bentgrass. HortScience 33:1023-1025.

Nabati, D.A., R.E. Schmidt, and D.J. Parrish. 1994. Alleviation of salinity stress in Kentucky bluegrass by plant growth regulators and iron. Crop Sci. 34:198-202.

Nardi, S., M.R. Panuccio, M.R.Abenavoli, and A. Muscolo. 1994. Auxinlike effect of humic substances extracted from faeces of Allolobophora caliginosa and A. rosea. Soil Biol. Biochem. 26:1341-1346.

Nooden, L.D. and A.C. Leopold. 1988. Senescence and Aging in Plants. Academic Press, London.

O'Donnell, R.W. 1973. The auxin-like effects of humic preparations from leonardite. Soil Sci. 116:106-112.

Papageorgiou, G.C., Y. Fujimura, and N. Murata. 1991. Protection of oxygen-evolving photosystem II complex by glycinebetaine. Biochem. Biophys. Acta 1057:361-66.

Polle, A. 1997. Defense against photooxidative damage in plants, p. 623-666. In: J.G. Scandalios (ed.). Oxidative stress and the molecula biology of antioxidant defenses. Cold Spring Harbor Lab Press, Plainview, N.Y.

Rhodes, D. and A.D. Hanson. 1993. Quarternary ammonium and tertiary sulfonium compounds in higher plants. Annu. Rev. Plant Physiol. Plant Mol. Biol. 44:357-384.

Sanderson, K.J. and P.E. Jameson. 1986. The cytokinins in a liquid seaweed extract: could they be the active ingredients? Acta Hort 179:113-116.

Sanderson, K.J., P.E. Jameson, and J.A. Zabkiewicz. 1987. Auxin in a seaweed extract: identification and quantitation of indole-3-acetic acid by gas chromatography-mass spectrometry. J. Plant Physiol. 129:363-367.

SAS Institute. 1996. SAS/STAT user's guide, version 6.12. SAS Inst., Cary, N.C.

Sachs, P.D. 1996. Handbook of successful ecological lawn care. EP Press, Newbury, Vt.

Scandalios, J.G. 1997. Molecular genetics of superoxide dismutases in plants, p. 527-568. In: J.G. Scandalios (ed.). Oxidative stress and the molecular biology of antioxidant defenses. Cold Spring Harbor Lab Press, Plainview, N.Y.

Schmidt, R.E., X. Zhang, and D.R. Chalmers. 1999. Responses of photosynthesis and superoxide dismutase to silica applied to creeping bentgrass grown under two fertility levels. J. Plant Nutr. 22:
$1763-1773$.

Senn, T.L. 1987. Seaweed and plant growth, p. 1-2. Clemson Univ., S.C.

Smirnoff, N. 1995. Antioxidant systems and plant response to environment, p. 217-244. In: N. Smirnoff (ed.). Environment and plant metabolism: flexibility and acclimation. BIOS Scientific Publ., Oxford, U.K.

White, R.H. 1996. Physiological basis for selection of bentgrass with superior drought resistance, p. 28-29. Turfgrass and environmnetal research summary. USGA, Far Hills, N.J.

Williams, W.P., A.P.R. Brain, and P.J. Dominy. 1992. Induction of nonbilayer lipid phase separations in chloroplast thylakoid membranes by compatible co-solutes and its relation to the thermal stability of photosystem II. Biochem. Biophys. Acta 1099:137-144.

Yan, J. 1993. Influence of plant growth regulators on turfgrass polar lipid composition, tolerance to drought and salinity stresses, and nutrient efficiency. PhD diss. (diss. abstr. 93 16828). Virginia Tech, Blacksburg, Va.

Yan, J. R.E. Schmidt, and D.M. Orcutt. 1997. Influence of fortified seaweed extract and drought stress on cell membrane lipids and sterols of ryegrass leaves. Intl. Turfgrass Res. J. 8:1356-1363.

Young, C.C. and L.F. Chen. 1997. Polyamines in humic acid and their effect on radical growth of lettuce seedlings. Plant and Soil. 195: 143-149.

Zhang, X. 1997. Influence of plant growth regulators on turfgrass growth, antioxidant status, and drought tolerance. PhD diss. (diss. abstr. 8597-161835). Virginia Tech, Blacksburg, Va.

Zhang, X. and R.E. Schmidt. 1997. The impact of growth regulators on the $\alpha$-tocopherol status in water-stresses Poa pratensis L. Intl. Turfgrass Res. J. 8:1364-1373.

Zhang, X. and R.E. Schmidt. 1999. Antioxidant response to hormonecontaining product in Kentucky bluegrass subjected to drought. Crop Sci. 39:545-551.

Zhang, X. and R.E. Schmidt. 2000a. Hormone-containing products impact on antioxidant status of tall fescue and creeping bentgrass subjected to drought. Crop Sci. 40:1344-1349.

Zhang, X. and R.E. Schmidt. 2000b. Application of trinexapac-ethyl and propiconazole enhances superoxide dismutase and photochemical activity in creeping bentgrass (Agrostis stolonifera var. palustris). J. Amer. Soc. Hort. Sci. 125:47-51. 